\title{
THE UTILIZATION OF FUEL DIESEL EMULSION AS A RESERVE SOURCE OF DIESEL FUEL FOR INDONESIAN WAR SHIPS
}

\author{
Abdul Rahman ${ }^{1}$, Dwi Kumara², Wawan Kusdiana ${ }^{3}$, Anton Nugroho ${ }^{4}$. \\ 1,2,3,4 Indonesian Naval Technology College, STTAL \\ Bumimoro-Moro Krembangan, Surabaya, 60178, Indonesia
}

\begin{abstract}
$B y$ the development of the time, diesel fuel is made from petroleum which is decreasing in number. Besides that, the emissions produced from burning diesel fuel can also cause air pollution. One of the methods used to minimize the use of diesel fuel and air pollution is by using emulsion fuel. therefore, a precautionary measure is required in preparing a reserve fuel source for Indonesian war ships. And one of the options is with emission diesel fuel. From the results of laboratory trials there was an increase in density, viscosity, flash point, cetane and TAN numbers and a decrease in residue, Lower Heating Value and calorific value. The performance test results show an increase in SFOC and thermal efficiency, but the power, torque and BMEP have decreased. So, it can be concluded that the emulsion HSD has decreased performance but can reduce emissions from the combustion process. So, it is hoped that emission diesel fuel can be used as an alternative as well as a solution to the limitations of diesel fuel in the future, so that it can support tni al operations in the future.
\end{abstract}

Keywords : Diesel fuel, diesel fuel emulsion, reserve fuel, Indonesian Navy Operations.

\section{INTRODUCTION}

\subsection{Background}

Fossil fuels or mineral fuels are natural resources that contain hydrocarbons such as coal, natural gas and petroleum. Fossil fuels come from the remains of living things that lived millions of years ago, which died and were buried on the ocean floor and rivers in a layer called sediment. Petroleum is the main source in the manufacture of diesel fuel, it is one of the natural resources that cannot be renewed and the number is decreasing, but the use of diesel fuel continues to increase due to the increasing use of diesel fueled engines, increasing consumption of diesel fuel in part. large used for land and sea transportation purposes.

In addition to the availability of diesel raw materials which are decreasing rapidly every year, there are also other factors that become a problem with the use of diesel fuel, namely the high level of pollution generated from the residual combustion products of diesel engines. Pollution due to exhaust emissions generated by diesel engines has a negative impact on the environment and health. Particles such as carbon monoxide (CO), hydrocarbons ( $\mathrm{HC}$ ), carbon dioxide (CO2), sulfuroxide (SOx) and nitrogenoxide (NOx), each of which has a negative impact on the environment and health (Sugiarti, 2009).

To reduce the use of diesel fuel and overcome various environmental pollution problems, it is necessary to have a new breakthrough in the production of diesel fuel that can minimize the use of diesel fuel and reduce pollution from the combustion of diesel fuel, one of these breakthroughs is to substitute use of diesel fuel with fuel mixed with water and diesel (diesel emulsion). which in previous research was stated to be able to reduce the residual combustion caused by incomplete combustion in diesel engines (Feng, Baoguo, Jiangping, Wuqiang, \& Bin, 2015).

Making HSD emulsion cannot be done directly because it requires special treatment and the addition of additives in the form of surfactants. The addition of surfactants was carried out to reduce surface tension and to bind the surface of HSD particles and water. From previous research, an analysis of emulsion emulsion combustion exhaust gas has been carried out which according to the analysis data is able to have a positive impact on the air environment by reducing a number of pollutants (Scarpete, 2013). This study will discuss the comparative analysis of the performance of HSD fuel used in KRI with HSD emulsion with a ratio of $\mathrm{HSD}(80 \%)$ and $\mathrm{H} 2 \mathrm{O}$ $(20 \%)$ and the addition of $4 \mathrm{ml}$ of surfactant in every $100 \mathrm{ml}$.

With the similarity of emulsion HSD characteristics with Pertamina HSD, the emulsion HSD fuel has the potential to be used as an alternative fuel for diesel engines and can reduce air pollution levels. 


\section{LITERATURE REVIEW}

\subsection{Emulsion Definition}

High Speed Diesel (HSD) is a type of diesel fuel that has a cetane performance number of 45 , this type of fuel is generally used for transportation engines for diesel engines commonly used with mechanical pump injection systems (injection pump) and electronic injection, this type of fuel is intended for this type of transportation. transportation motor vehicles and industrial machines (BPHMigas, 2007).

Emulsion of water in oil is defined as the form of a mixture of water in oil which does not mix with each other, is forced to mix stably or temporarily with the help of surfactant chemicals (emuslifier) so that water in the form of granules is distributed into the oil phase (Bindar, 2015). Fuel emulsification is determined by several factors, namely surfactant ability, liquid viscosity, mixture composition, temperature and grain size. The smaller the grain size, the more stable the emulsion will be over a longer time. A water-inoil emulsion is formed when the volume of water is much less than the volume of oil mixed.

In order for the oil-in-water emulsion to be stable for a long time, the surfactant or emulsifier ability is the key. Water-in-oil emulsion can be used as fuel where this emulsion can certainly burn (Bindar, 2015).

\subsection{Surfactants}

Surfactants or Surface Active Agents are molecules consisting of non-polar and polar groups, if the surfactant is used as a solvent in water, it consists of hydrophilic (water-loving) and hydrophobic (water-hating) groups. If the surfactant is used as a solvent in oil or fat, the group consists of lipophobic (oil-disliking) and lipophilic (oil-loving). Surfactants are divided into two parts, namely head and tail. The hydrophilic group is on the head (polar) and lipophilic on the tail (non-polar).

The polar parts of the surfactant molecule can be positively, negatively or neutral in charge. Generally the non-polar (lipophilic) part is a long alkyl chain, while the polar (hydrophilic) part contains a hydroxyl group (the -OH functional group which is used as a substituent in an organic compound) while the non-polar part is usually an alkyl chain (carbon and hydrogen atoms). with the long $\mathrm{CnH} 2 n+1)$ arrangement.

In order for the oil-in-water emulsion to be stable for a long time, the surfactant or emulsifier ability is the key. Water-in-oil emulsion can be used as fuel where this emulsion can certainly burn (Bindar, 2015).

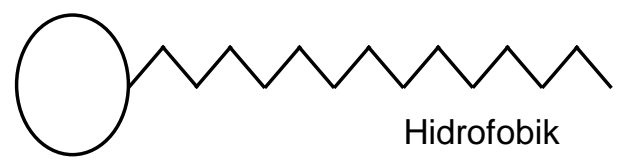

Hidrofilik

Figure 1. Surfactan's Parts

Broadly speaking, surfactants are classified into 2 parts, namely:

a. Oil-soluble surfactants

b. Water soluble surfactants

Surfactants can reduce the surface tension of water by breaking hydrogen bonds on the surface. This can happen because the hydrophilic heads tend to be on the surface of the water, with the hydrophobic tails stretching away from the surface of the water.

The addition of surfactants in solution will cause a decrease in the surface tension of the solution, after the surfactants reach a certain concentration in the solution, the addition of surfactants can no longer reduce surface tension, this is called Critical Micelle Concentration. If the surfactant in solution exceeds the critical concentration, it will result in the formation of micelles (Farn, 2006).

\subsection{HLB (Hidrophile-Lipophile Balance)}

HLB is one of the values that can be used to measure the properties of a surfactant, the HLB value starts from 0 to 20 , with a middle limit of 10 . If the HLB value of a surfactant is below 10 , then the surfactant has more oil-like or lipophilic properties, the further away from it. number 10 the surfactant is increasingly like oil. Meanwhile, surfactants that have HLB values above 10 , then the surfactants like water or hydrophilic are more dominant.

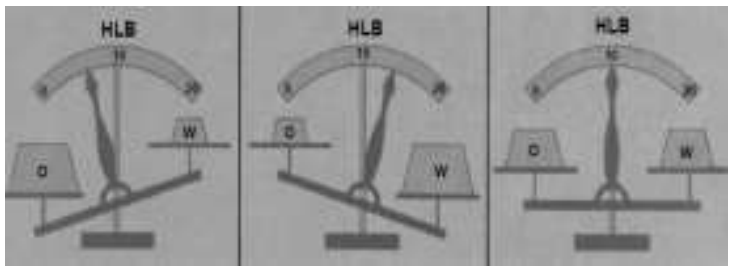

Figure2. Surfactant Properties According to HLB Value

The following are some types of surfactants with different HLB values. 
Table 1. HLB Value on Surfactants

\begin{tabular}{|c|c|c|}
\hline NO & SURFACTANT & HLB \\
\hline 1. & $\begin{array}{c}\text { Sorbitan Trioleate } \\
\text { (Span 85) }\end{array}$ & 1,8 \\
\hline 2. & $\begin{array}{c}\text { Sorbitan } \\
\text { Monostearate (Span } \\
\text { 60) }\end{array}$ & 4,3 \\
\hline 3. & $\begin{array}{c}\text { Sorbitan Monooleate } \\
\text { (Span 80) }\end{array}$ & 4,7 \\
\hline 4. & $\begin{array}{c}\text { Sonopalmitate (Span } \\
\text { 40) }\end{array}$ & 6,7 \\
\hline 5. & $\begin{array}{c}\text { Sorbitan Monolaurate } \\
\text { (Span 20) }\end{array}$ & 8,6 \\
\hline 6. & $\begin{array}{c}\text { Polyxyethylene } \\
\text { Sorbitan (Span 85) }\end{array}$ & 11 \\
\hline 7. & $\begin{array}{c}\text { Polysorbate 60 } \\
\text { (Tween 60) }\end{array}$ & 14,9 \\
\hline 8. & $\begin{array}{c}\text { Polysorbate 40 } \\
\text { (Tween 40) }\end{array}$ & 15 \\
\hline 9. & $\begin{array}{c}\text { Polysorbate 80 } \\
\text { (Tween 80) }\end{array}$ & 15,6 \\
\hline 10. & $\begin{array}{c}\text { Polysorbate 20 } \\
\text { (Tween 20) }\end{array}$ & 16,7 \\
\hline
\end{tabular}

Source: (Dubey \& Saxena, 2016)

Each surfactant has a certain HLB value with its own characteristics, whereas to make an emulsion solution requires an HLB value which is sometimes not owned by surfactants, therefore it is necessary to use more than one type of surfactant with different HLB values in order to obtain the HLB value accordingly. needs. Here are the types of emulsions according to the HLB value.

Table 2. Types of Emulsion according to the HLB value

\begin{tabular}{|c|c|l|}
\hline NO & HLB VALUE & TYPE OF EMULSION \\
\hline 1. & $<10$ & Fat soluble \\
\hline 2. & $>10$ & Water soluble \\
\hline 3. & $4-8$ & Anti-foaming agent \\
\hline 4. & $7-11$ & Water-in-oil emulsifier \\
\hline 5. & $12-16$ & Emulsifier of oil in oilk \\
\hline 6. & $11-14$ & Dispersing agent \\
\hline
\end{tabular}

\begin{tabular}{|c|c|l|}
\hline 7. & $12-15$ & Detergent \\
\hline 8. & $16-20$ & Solvent \\
\hline
\end{tabular}

The table above is an outline of the HLB requirements to make emulsions according to their respective characteristics. Every time a different emulsion is used, the HLB value will also change. To make an emulsifying agent (surfactant) in accordance with HLB, a value of (X) using surfactant $A$ and surfactant $B$ can be done by calculating according to the following formula (Chemmunique, 1980).

$$
\begin{gathered}
\%(A)=\frac{100\left(X-H L B_{B}\right)}{H L B_{A^{-}} H L B_{B}} \\
\%(B)=100-\%(A)
\end{gathered}
$$

\section{$2.4 \quad$ Fuel Characteristics}

Solar is a type of fossil fuel that contains hydrocarbons $(\mathrm{C}$ and $\mathrm{H})$. Basically, petroleum obtained from drilling wells still contains other substances or elements so that it cannot be used as fuel. In oil refineries, there is a stage that can be considered as an important stage when the metah oil is processed, this stage is called distillation. The quality of petroleum products depends on the processing and quality of crude oil obtained. In order to determine the quality of the fuel, certain values must be standardized for the characteristics of the fuel, as follows:
a. Cetane Number (CN).
b. $\quad$ Cetane Index $(\mathrm{Cl})$.
c. Specific Gravity (SG)
d. Viscosity
e. Sulfur Content
f. Flash Point
g. Pour Point
h. Conradson Carbon Residue (CCR)
i. Water Content
j. Copperstrips Corrosion
k. Ash Content
I. Strong acid number
m. Total Acid Number

\subsection{Performance Test}

Diesel motor is a special type of internal combustion engine. The main characteristic of a diesel engine that distinguishes it from other combustion engines lies in the fuel ignition method. In a diesel motor, fuel is injected into a cylinder containing high pressure air. During the process of compressing the air in the engine cylinder, the air temperature increases, so that when the fuel in the form of fine mist comes into 
contact with this hot air, the fuel will ignite itself without the help of another ignition device. The combustion process of a diesel engine is a fast chemical reaction between fuel and oxygen from the air in the combustion chamber. The grains of fuel sprayed in the combustion chamber will mix with oxygen, which then at a certain pressure and temperature causes the fuel combustion process to occur in the combustion chamber. The carbon element and the element hydrogen are the main combustible elements in the fuel.

\section{RESEARCH METHOD}

\subsection{Making Emulsion Fuel}

Water-in-oil emulsion is defined as a mixture of water in oil which is not mixed with each other, is forced to mix stably or temporarily with the help of a chemical surfactant (emuslifier) so that water in the form of granules is distributed into the oil phase. Fuel emulsification is determined by several factors, namely surfactant ability, liquid viscosity, mixture composition, temperature and grain size. The smaller the grain size, the more stable the emulsion will be for a longer time. A waterin-oil emulsion is formed when the volume of water is much less than the volume of oil mixed.

In order for the oil-in-water emulsion to be stable for a long time, the surfactant or emulsifier ability is the key. Water-in-oil emulsion can be used as a fuel which of course can burn. In order for the oil-in-water emulsion to be stable for a long time, the surfactant or emulsifier ability is the key. Water-in-oil emulsion can be used as fuel where this emulsion can certainly burn (Bindar, 2015).

The emulsion fuel to be made is fuel with a ratio of HSD and distilled water composition of $80: 20$ from $100 \mathrm{ml}$ with the addition of $4 \mathrm{ml}$ surfactant for every $100 \mathrm{ml}$, determining the HLB value and mixing method will affect the quality and duration of the mixing process.

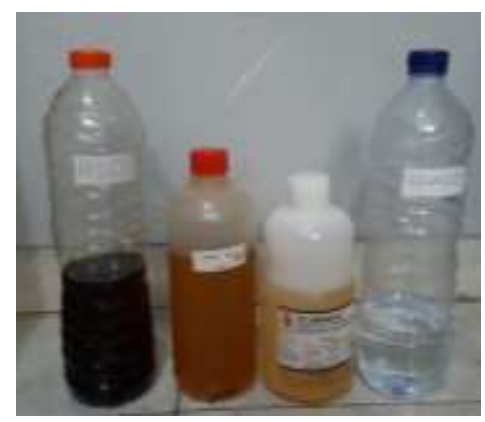

Figure 3. Raw Materials for HSD Emulsion Fuel
HLB is one of the values that can be used to measure the properties of a surfactant, the HLB value starts from 0 to 20 , with a middle limit of 10 . If the HLB value of a surfactant is below 10 , then the surfactant has oil-like or lipophilic properties more dominant, the farther away from number 10 the surfactant is increasingly like oil. Meanwhile, surfactants that have HLB values above 10, then the surfactants like water or their hydrophilic properties are more dominant.

From the diata material, a trial was conducted to select the appropriate HLB value to produce emulsion fuel with the best homogeneity. The HLB values tested were 5,9, $7,8,9,1,10,2$ and 10,7 with the composition of span 80 and tween 80 as follows:

Table 3. List of HLB uses

\begin{tabular}{|c|c|c|c|}
\hline NO & $\begin{array}{c}\text { SPAN 80 } \\
\text { (\%) }\end{array}$ & $\begin{array}{c}\text { TWEEN 80 } \\
\text { (\%) }\end{array}$ & HLB VALUE \\
\hline 1. & 85 & 15 & 5,9 \\
\hline 2. & 75 & 25 & 7 \\
\hline 3. & 65 & 35 & 8 \\
\hline 4. & 55 & 45 & 9,1 \\
\hline 5. & 45 & 55 & 10,2 \\
\hline 6. & 40 & 60 & 10,7 \\
\hline
\end{tabular}

In one experiment using $100 \mathrm{ml}$ of the total volume of emulsion fuel consisting of $80 \mathrm{ml}$ $\mathrm{HSD}, 20 \mathrm{ml} \mathrm{H} 2 \mathrm{O}$ and $4 \mathrm{ml}$ of surfactant. Mixing is done by stirring HSD with tween 80 and span 80 in the blender in a rotating condition for 5 minutes until the HSD and surfactant are completely mixed, after they are completely mixed, add $\mathrm{H} 2 \mathrm{O}$ little by little until it runs out (+ 3 minutes), let the HSD and surfactant From the results of mixing for 1 hour in a blender with a rotation speed of $15,000 \mathrm{Rpm}$, the emulsion fuel is obtained as shown in the image below.

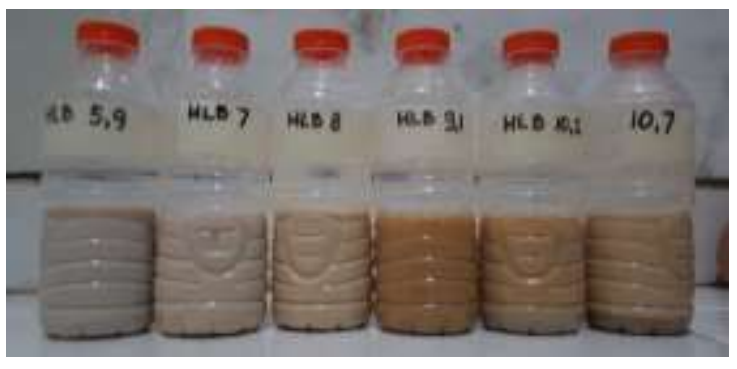

Figure 4. The results of making HSD emulsion with various HLB values

From the picture above, it can be seen that the most suitable HLB value is 5.9. Milky white color (not transparent) and does not produce water or gel deposits after leaving it for 5 (five) days. After knowing the most suitable 
HLB value, the next step is to make HSD emulsion with more scale. In a single manufacturing process the maximum is $200 \mathrm{ml}$ and it is maintained that the temperature in the stirrer does not exceed $50^{\circ} \mathrm{C}$ to reduce evaporation. The stirring process lasts for 2 hours with an interval of 10 minutes of stirring and 10 minutes of stopping. The process of mixing is carried out continuously until the HSD emulsion initially has a milky white color and initially has a lot of foam, so that the foam is not too much and the edges are transparent.

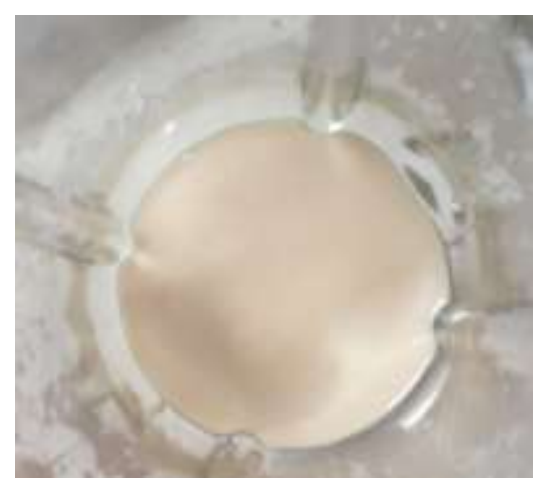

Figure 5. HSD Emulsion Color Change during the stirring process

\subsection{Performance Test}

The performance test is carried out to determine the power, BMEP torque, thermal efficiency and SFOC of the diesel motor using HSD fuel and HSD emulsion. In the performance test, the performance parameters to evaluate the performance of a combustion motor include:

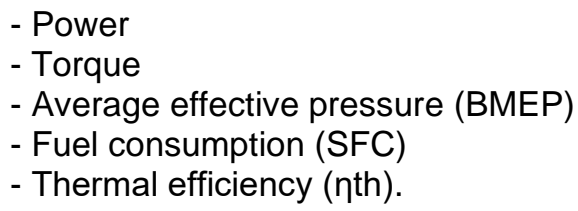

\subsection{Experimental Data Using HSD}

Data collection was carried out directly during the HSD fuel experiment.The results of data collection during the experiment using HSD were as on the following page.

Table 4. Result of Calculation of Power, Torque, BMEP

\begin{tabular}{|c|c|c|c|c|c|c|}
\hline \multirow{2}{*}{ NO } & \multirow{2}{*}{$\begin{array}{l}\text { PUTARAN } \\
\text { MESIN } \\
\text { (RPM) }\end{array}$} & \multirow{2}{*}{$\begin{array}{l}\text { PUTARAN } \\
\text { GENERATOR } \\
\text { (RPM) }\end{array}$} & \multirow{2}{*}{$\begin{array}{l}\text { BEBAN } \\
\text { (Watt) }\end{array}$} & \multicolumn{2}{|c|}{ ALTERNATOR } & \multirow{2}{*}{$\begin{array}{c}\text { WAKTU } \\
\text { (s) }\end{array}$} \\
\hline & & & & $\begin{array}{c}\text { TEGANGAN } \\
\text { (Volt) }\end{array}$ & $\begin{array}{c}\text { ARUS } \\
\text { (Ampere) }\end{array}$ & \\
\hline 1 & 1800 & 1136 & 1000 & 156 & 3,92 & 116,88 \\
\hline 2 & 1800 & 1136 & 2000 & 163 & $\mathrm{~B}$ & $95,8 \mathrm{~B}$ \\
\hline 3 & 1800 & 1136 & 3000 & 166 & 12,19 & 79,63 \\
\hline 4 & 1800 & 1135 & 4000 & 170 & 16,23 & 76,48 \\
\hline 5 & 1800 & 1132 & 5000 & 165 & 20,1 & 54,51 \\
\hline 1 & 1900 & 1198 & 1000 & 163 & 4,03 & 110,22 \\
\hline 2 & 1900 & 1197 & 2000 & 172 & 8,26 & 92,66 \\
\hline 3 & 1900 & 1196 & 3000 & 177 & 12,57 & 76,62 \\
\hline 4 & 1900 & 1197 & 4000 & 179 & 16,97 & 69,96 \\
\hline 5 & 1900 & 1197 & 5000 & 176 & 20,43 & 50,52 \\
\hline 1 & 2000 & 1264 & 1000 & 174 & 4,09 & 116,91 \\
\hline 2 & 2000 & 1265 & 2000 & 182 & 8,41 & 91,96 \\
\hline 3 & 2000 & 1259 & 3000 & 185 & 12,82 & 79,74 \\
\hline 4 & 2000 & 1258 & 4000 & 189 & 17,37 & 68,36 \\
\hline 5 & 2000 & 1259 & 5000 & 185 & 21,43 & 48,95 \\
\hline 1 & 2100 & 1324 & 1000 & 187 & 4,27 & 105,66 \\
\hline 2 & 2100 & 1325 & 2000 & 193 & 8,71 & 90,56 \\
\hline 3 & 2100 & 1320 & 3000 & 197 & 13,29 & 70,83 \\
\hline 4 & 2100 & 1321 & 4000 & 201 & 17,78 & 63,22 \\
\hline 5 & 2100 & 1319 & 5000 & 196 & 22,15 & 45,07 \\
\hline 1 & 2200 & 1389 & 1000 & 200 & 4,43 & 95,95 \\
\hline 2 & 2200 & 1388 & 2000 & 206 & 9,02 & 71,09 \\
\hline 3 & 2200 & 1386 & 3000 & 210 & 13,76 & 61,6 \\
\hline 4 & 2200 & 1384 & 4000 & 210 & 18,57 & 54,89 \\
\hline 5 & 2180 & 1368 & 5000 & 204 & 22,71 & 34,28 \\
\hline
\end{tabular}


After knowing the values of some of the parameters above, the next calculation is carried out to determine the SFOC value for each round.

Table 5. SFC Calculation Results, Thermal Efficiency

\begin{tabular}{|c|c|c|c|c|c|}
\hline No & $\begin{array}{c}\text { Jumlah } \\
\text { Bahan Bakar } \\
(\mathrm{Kg})\end{array}$ & $\begin{array}{c}\mathrm{SFC} \\
(\mathrm{Kg} / \mathrm{kWh})\end{array}$ & $\begin{array}{c}\text { Kec. Aliran } \\
\text { Bahan Bakar } \\
(\mathrm{Kg} / \mathrm{h})\end{array}$ & $\begin{array}{c}\text { Jml. Kalor } \\
\text { Masuk } \\
(\mathrm{Qm})\end{array}$ & $\begin{array}{c}\text { Eff. } \\
\text { Thermal } \\
(\%)\end{array}$ \\
\hline 1 & 0,016808 & 0,720 & 0,517700205 & 727,097272 & 11,565 \\
\hline 2 & 0,016808 & 0,411 & 0,831088861 & 727,097272 & 20,230 \\
\hline 3 & 0,016808 & 0,319 & 0,759874419 & 727,097272 & 26,072 \\
\hline 4 & 0,018808 & 0,244 & 0,791171548 & 727,097272 & 34,143 \\
\hline 5 & 0,018808 & 0,284 & 1,110049532 & 727,097272 & 29,251 \\
\hline 1 & 0,018808 & 0,710 & 0,548982038 & 727,097272 & 11,715 \\
\hline 2 & 0,016808 & 0,391 & 0,853019642 & 727,097272 & 21,300 \\
\hline 3 & 0,016808 & 0,302 & 0,78972592 & 727,097272 & 27,583 \\
\hline 4 & 0,016808 & 0,242 & 0,88490566 & 727,097272 & 34,385 \\
\hline 5 & 0,016808 & 0,283 & 1,19771 & 727,0 & 29,392 \\
\hline 1 & 0,016808 & 0,618 & 0,51756736 & 727,097272 & 13,462 \\
\hline 2 & 0,016808 & 0,365 & 0,857990431 & 727,097272 & 22,775 \\
\hline 3 & 0,018808 & 0,272 & 0,758826185 & 727,097272 & 30,600 \\
\hline 4 & 0,018808 & 0,229 & 0,88514921 & 727,097272 & 36,312 \\
\hline 5 & 0,018808 & 0,265 & 1,236134831 & 727,097272 & 31,400 \\
\hline 1 & 0,016808 & 0,610 & 0,572674617 & 727,097272 & 13,651 \\
\hline 2 & 0,016808 & 0,338 & 0,868162544 & 727,097272 & 24,632 \\
\hline 3 & 0,018808 & 0,277 & 0,854282084 & 727,097272 & 30,005 \\
\hline 4 & 0,018808 & 0,228 & 0,857114837 & 727,097272 & 36,557 \\
\hline 5 & 0,016808 & 0,263 & 1,342551586 & 727,097272 & 31,680 \\
\hline 1 & 0,016808 & 0,605 & 0,830828452 & 727,097272 & 13,755 \\
\hline 2 & 0,016808 & 0,389 & 0,851157687 & 727,097272 & 21,373 \\
\hline 3 & 0,018808 & 0,289 & 0,982285714 & 727,097272 & 28,801 \\
\hline 4 & 0,016808 & 0,240 & 1,102364729 & 727,097272 & 34,635 \\
\hline 5 & 0,016808 & 0,324 & 1,765134189 & 727,097272 & 25,697 \\
\hline
\end{tabular}

From the results of the calculations outlined in the table, the existing data can be displayed as in the following graph. 


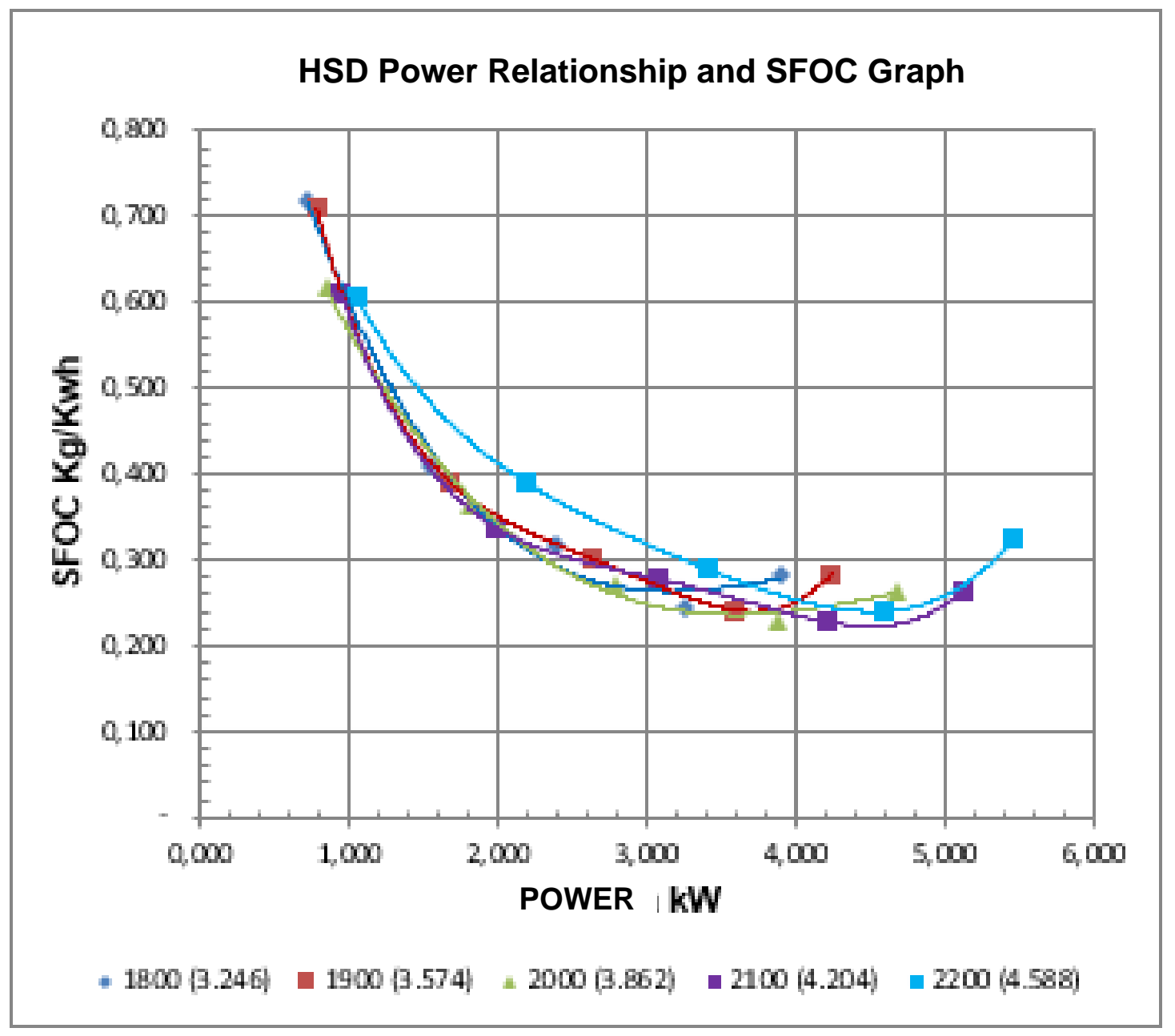

Figure 6. HSD Power Relationship and SFOC Graph

Figure 6 is a graph showing the relationship between the power generated by the engine and SFOC when using HSD fuel.From this graph, it can be seen that the lowest SFOC is obtained at $2100 \mathrm{Rpm}$ with a power of 4,204 Watts and an SFOC of $0.228 \mathrm{Kg}$ / Kwh, and is followed by $2200 \mathrm{Rpm}$ with a load of 4,588 Watt has an SFOC value of $0.240 \mathrm{Kg} /$ $\mathrm{kWh}$. In the $2000 \mathrm{Rpm}$ rotation, it is capable of producing 3,862 Watt of power and an SFOC of $0.229 \mathrm{KgkWh}$. At the $1800 \mathrm{Rpm}$ rotation it produces a power of 3,246 Watt with an SFOC of $0.259 \mathrm{Kg} / \mathrm{Kwh}$, at $1900 \mathrm{Rpm}$ with a load of 3.574 Watt has an SFOC of $0.242 \mathrm{Kg} / \mathrm{kWh}$. The lowest points of the curved graph line from each rotation can be interpreted as the best fuel efficiency and maximum load at that rotation.

\subsection{Experimental data using HSD Emulsion}

Data collection is carried out directly during the HSD fuel experiment, which shows the results of data collection during the experiment using HSD are as on the following page. It will show the comparison between rpm, SFOC, speed of fuel flow LHV the the amount of heat entered, and thermal efficiency. 
Table 6. SFOC calculation results, thermal efficiency

\begin{tabular}{|c|c|c|c|c|c|c|}
\hline No & RPM & $\begin{array}{c}\text { SFOC } \\
(\mathrm{Kg} / \mathrm{kWh})\end{array}$ & $\begin{array}{c}\text { Speed Fuel } \\
\text { Flow } \\
\text { Kg/h }\end{array}$ & $\underset{(\mathrm{kJ} / \mathrm{kg})}{\mathrm{LHV}}$ & $\begin{array}{c}\text { Jml. } \\
\text { Kalor } \\
\text { Masuk } \\
(\text { Qm) }\end{array}$ & $\begin{array}{c}\text { Eff. } \\
\text { Thermal } \\
(\%)\end{array}$ \\
\hline 1 & 1800 & 0,816 & 0,555060239 & 33140 & 557,8263 & 13,57 \\
\hline 2 & 1800 & 0,480 & 0,709266713 & 33140 & 557,8263 & 23,08 \\
\hline 3 & 1800 & 0,355 & 0,820089547 & 33140 & 557,8263 & 31,22 \\
\hline 4 & 1800 & 0,303 & 0,941515207 & 33140 & 557,8263 & 36,59 \\
\hline 5 & 1800 & 0,311 & 1,199504978 & 33140 & 557,8263 & 35,59 \\
\hline 1 & 1900 & 0,765 & 0,629272464 & 33140 & 557,8263 & 13,47 \\
\hline 2 & 1900 & 0,463 & 0,765733947 & 33140 & 557,8263 & 23,92 \\
\hline 3 & 1900 & 0,346 & 0,891406176 & 33140 & 557,8263 & 31,97 \\
\hline 4 & 1900 & 0,308 & 1,066568909 & 33140 & 557,8263 & 36,02 \\
\hline 5 & 1900 & 0,355 & 1,471952272 & 33140 & 557,8263 & 31,19 \\
\hline 1 & 2000 & 0,698 & 0,607698598 & 33140 & 557,8263 & 15,87 \\
\hline 2 & 2000 & 0,455 & 0,843284656 & 33140 & 557,8263 & 24,32 \\
\hline 3 & 2000 & 0,334 & 0,944730623 & 33140 & 557,8263 & 33,20 \\
\hline 4 & 2000 & 0,294 & 1,086640745 & 33140 & 557,8263 & 37,72 \\
\hline 5 & 2000 & 0,337 & 1,567638894 & 33140 & 557,8263 & 32,89 \\
\hline 1 & 2100 & 0,662 & 0,653663972 & 33140 & 557,8263 & 16,74 \\
\hline 2 & 2100 & 0,421 & 0,853103584 & 33140 & 557,8263 & 26,31 \\
\hline 3 & 2100 & 0,322 & 1,005208126 & 33140 & 557,8263 & 34,38 \\
\hline 4 & 2100 & 0,292 & 1,147327467 & 33140 & 557,8263 & 37,88 \\
\hline 5 & 2100 & 0,318 & 1,554360745 & 33140 & 557,8263 & 34,88 \\
\hline 1 & 2200 & 0,677 & 0,740349176 & 33140 & 557,8263 & 16,36 \\
\hline 2 & 2200 & 0,416 & 0,983657538 & 33140 & 557,8263 & 25,11 \\
\hline 3 & 2200 & 0,345 & 1,198171944 & 33140 & 557,8263 & 31,33 \\
\hline 4 & 2185 & 0,322 & 1,366987962 & 33140 & 557,8263 & 34,39 \\
\hline
\end{tabular}

The results of the calculation from the data in the table, for more details, can be displayed with a SFOC graph and the power generated at each engine RPM as shown in the graph on the next page.

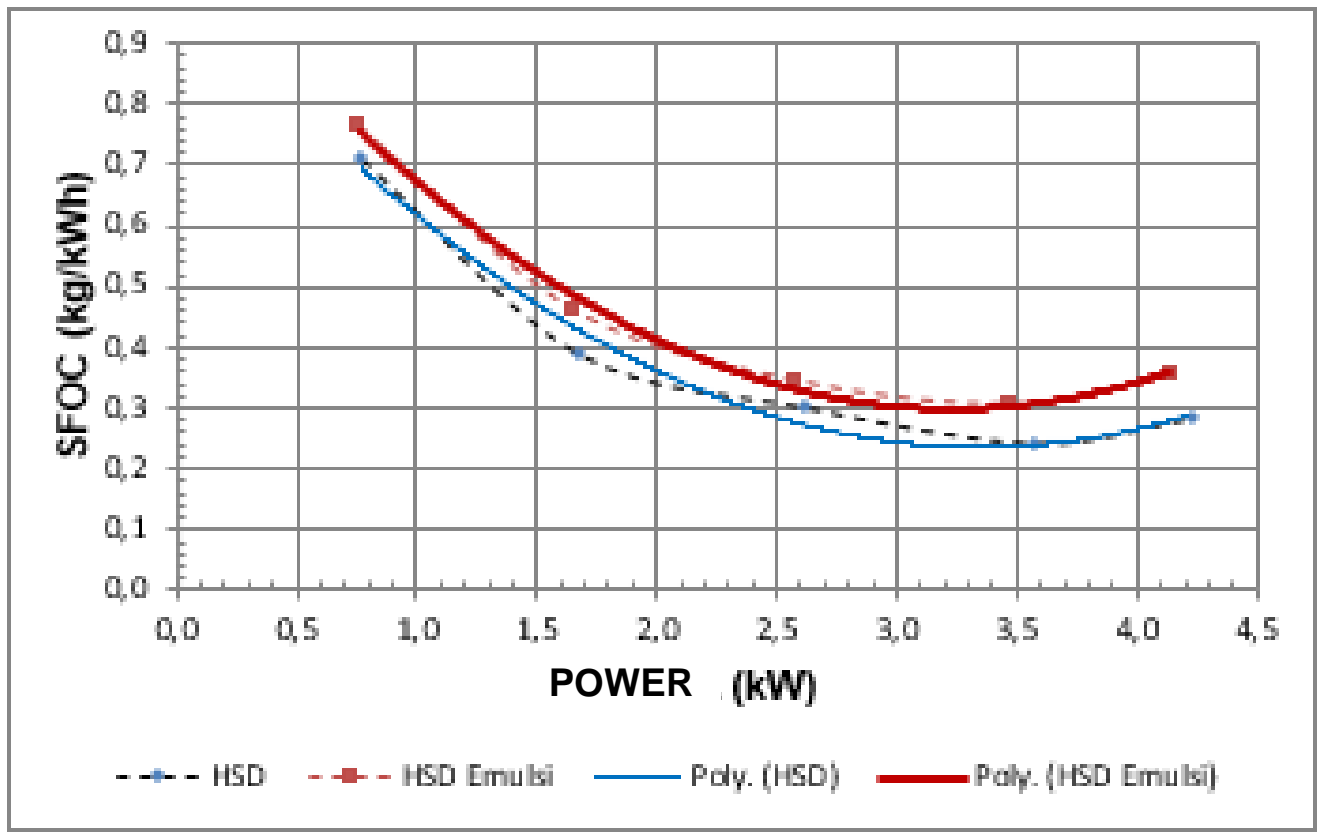

Figure 7. SFOC Graph and HSD and HSD Emulsion Usage Power at 1900 Rpm round 
The picture above is a graph depicting the relationship between the Specific Fuel Oil Consumption and the power generated by a diesel engine from the use of HSD and HSD emulsion fuel at $1900 \mathrm{Rpm}$ engine speed. According to the graph above, the lowest SFOC value is owned by HSD fuel with an SFOC value of $0.242 \mathrm{Kg} / \mathrm{kWh}$ and is capable of producing a power of $3.574 \mathrm{~kW}$. Meanwhile, when using emulsion fuel, the lowest SFOC value is 0.308 $\mathrm{Kg} / \mathrm{kWh}$ which produces a power of $3,468 \mathrm{~kW}$. When the load is lowest, the SFOC HSD value is $0.71 \mathrm{Kg} / \mathrm{kWh}$ and the SFOC HSD emulsion value is $0.822 \mathrm{Kg} / \mathrm{kWh}$, an increase of 0.112 $\mathrm{Kg} / \mathrm{Kwh}$. When the load is highest at 1900 Rpm. The SFOC HSD value is $0.283 \mathrm{Kg} / \mathrm{kWh}$, and the SFOC HSD emulsion value is $0.311 \mathrm{Kg}$ / $\mathrm{kWh}$, an increase of $0.028 \mathrm{Kg} / \mathrm{Kwh}$.

\section{CONCLUSIONS AND SUGGESTIONS}

\subsection{Conclusions}

The conclusions obtained based on the Design of Mechanisms and Motion Systems in Prototype Tanks Using Odometry that have been made, can be mentioned, namely:

a. Comparison of the characteristics between emulsion HSD and HSD fuels, there are significant differences in the specific gravity, heating value, flash point, LHV and cetane number, even the specific gravity and viscosity of the emulsion HSD has exceeded the maximum limits of diesel fuel specifications. For other characteristics such as TAN, sulfur, ash, carbon content and kinematic viscosity differ only slightly and are still within the permissible standards. The water content, sediment and corrosion of the copper blades of both types of fuel are equally good.

b. The performance comparison between emulsion HSD and HSD fuels has differences in power, torque, BMEP, SFOC, thermal efficiency. HSD fuels are better at generating power, torque, BMEP and have a lower average SFOC than emulsion HSD. Whereas HSD emulsion is better in terms of thermal efficiency.

\subsection{Suggestions}

Based on the research results of the Design of Mechanisms and Motion Systems in Prototype Tanks Using Odometry that has been done by the author, it can be given suggestions for further system development. These suggestions can be explained as follows:

a. Future research can examine the preparation of HSD emulsion with a higher mixture of water, to obtain more emission reduction data, but still maintain the specific gravity and viscosity of the emulsion fuel.

b. Future studies can examine noise levels by comparing and studying the effect of using HSD emulsions on the noise level, whether different cetane numbers and heating values will affect the noise level..

\section{ACKNOWLEDGEMENT}

The authors greatly acknowledge the support from Naval Technology College, STTAL Surabaya Indonesia for providing the necessary resources to carry out this research work. The authors are also grateful to the anonymous reviewers and journal editorial board for their many insightful comments, which have significantly improved this article.

\section{REFERENCES}

Abu-Zaid, M. (2003). Performance of Single Cylinder, Direct Injection Diesel Engine Using Water Fuel Emulsion. Elsevier , 697-705.

Arif, S. (2004). Analisa Getaran dan Kebisingan Pada Motor Diesel Dengan Menggunakan Bahan Bakar Jelantah Ethyl Ester. Surabaya: Institut Teknologi Sepuluh Nopember.

Attia, A. M., \& Kulchitskiy, A. (2013). Influence of the structure of water-in-fuel emulsion on diesel engine. Science Direct, 703-708.

Bindar, Y. (2015, Oktober). Tinjauan Penggunaan Air Teremulsi Dalam Minyak Bakar Sebagai Bahan Bakar Industri dan Mesin Diesel: Apakah Menguntungkan atau Merugikan dan Apa Permasalahan Standarisasinya? On Mei 6, 2018, from www.researchgate.net:

https://www.researchgate.net/publica tion/283044466_Tinjauan_Penggun aan_Air_Teremulsi_Dalam_Minyak Bakar_Sebagai_Bahan_Bakar_Indu stri_dan_Mesin_Diesel_Apakah_Me nguntungkan_atau_Merugikan_dan_ Apa_Permasalahan_Standarisasiny a_1

BPHMigas. (2007). komoditas BBM. On July 2, 2018, from www.bphmigas.go.id: http://www.bphmigas.go.id/komodita s-bbm 
Chemmunique. (1980). The HLB System a Time Saving Guide to Emulsifier Selection. Wilmington, Delaware 19897: ICI Americas Inc.

Dubey, M., \& Saxena, D. V. (2016). Impact of Emulsified Water/Diesel Mixture on Engine Performance and Environment. International Journal of Engineering and Technology (IJETT) , Page 461-466.

Farn, R. J. (2006). Chemistry and Technology of Surfactant. Oxford: Blachwell Publishing.

Feng, L., Baoguo, d., Jiangping, T., Wuqiang, L., \& Bin, T. (2015, December 1). Combustion Performance and Emission Characteristics of a Diesel Engine Using a Water-Emulsified Heavy Fuel Oil and Light Diesel Blend. Energies , Page. 1362813640.

Ismail, Nova, D., Suparmanto, N., Rahayu, D., \& Rusliyanto. (2012). Pengaruh Emulgator Buah Lerak (sapindus rarak) Dengan Emulsi Air Dan Solar Sebagai Bahan Bakar Motor Diesel Ramah Lingkungan. PELITA, Page 29-37.

Pertamina. (2016, juli 31). Spesifikasi solar dan biosolar. Dipetik juni 25, 2018, From: www.pertamina.com:

https://www.pertamina.com/industrial fuel/media/6796/biosolar.pdf

Sarjono. (2009). Penggunaan Bahan Bakar Emulsi Sebagai Bahan Bakar Alternatif Pada Mesin Diesel. Cepu: Majalah IImiah STTR Cepu.

Scarpete, D. (2013). Diesel-Water Emulsion, An Alternative Fuel to Reduce Diesel Engine Emission. a Review. Machines, Technologi, Material , Page. 13-16.

Sudrajad, A., Ipic, S., \& Achmad, F. (2015). Analisa Thermal Gravimetric Analysis Bahan Bakar Emulsi. Jurnal Teknik Mesin Untirta, Page 66-70.
Sugiarti. (2009). Gas Pencemar Udara dan Pengaruhnya Bagi Kesehatan Manusia. Jurnal Chemical , Page 5058.

Tirtoatmodjo, W. R., \& Willyanto, F. (1999). Peningkatan Unjuk Kerja Motor Diesel dengan Penambahan Pemanas Solar. Jurnal Teknik Mesin , Page 127-133. 